\title{
Snowpack concentrations and estimated fluxes of volatile organic compounds in a boreal forest
}

\author{
H. Aaltonen ${ }^{1,2}$, J. Pumpanen ${ }^{1}$, H. Hakola ${ }^{2}$, T. Vesala ${ }^{3}$, S. Rasmus ${ }^{4}$, and J. Bäck ${ }^{1,3}$ \\ ${ }^{1}$ Department of Forest Sciences, P.O. Box 27, 00014 University of Helsinki, Finland \\ ${ }^{2}$ Finnish Meteorological Institute, P.O. Box 503, 00101 Helsinki, Finland \\ ${ }^{3}$ Department of Physics, P.O. Box 48, 00014 University of Helsinki, Finland \\ ${ }^{4}$ Department of Biological and Environmental Sciences, P.O. Box 35, 40014 University of Jyväskylä, Finland
}

Correspondence to: H. Aaltonen (hermanni.aaltonen@ @elsinki.fi)

Received: 14 October 2011 - Published in Biogeosciences Discuss.: 16 January 2012

Revised: 4 May 2012 - Accepted: 14 May 2012 - Published: 7 June 2012

\begin{abstract}
Soil provides an important source of volatile organic compounds (VOCs) to atmosphere, but in boreal forests these fluxes and their seasonal variations have not been characterized in detail. Especially wintertime fluxes are almost completely unstudied. In this study, we measured the VOC concentrations inside the snowpack in a boreal Scots pine (Pinus sylvestris L.) forest in southern Finland, using adsorbent tubes and air samplers installed permanently in the snow profile. Based on the VOC concentrations at three heights inside the snowpack, we estimated the fluxes of these gases. We measured 20 VOCs from the snowpack, monoterpenes being the most abundant group with concentrations varying from 0.11 to $16 \mu \mathrm{g} \mathrm{m}^{-3}$. Sesquiterpenes and oxygencontaining monoterpenes were also detected. Inside the pristine snowpack, the concentrations of terpenoids decreased from soil surface towards the surface of the snow, suggesting soil as the source for terpenoids. Forest damages (i.e. broken treetops and branches, fallen trees) resulting from heavy snow loading during the measurement period increased the terpenoid concentrations dramatically, especially in the upper part of the snowpack. The results show that soil processes are active and efficient VOC sources also during winter, and that natural or human disturbance can increase forest floor VOC concentrations substantially. Our results stress the importance of soil as a source of VOCs during the season when other biological sources, such as plants, have lower activity.
\end{abstract}

\section{Introduction}

Volatile organic compound (VOC) emissions in boreal forests at the branch and canopy levels have been rather well characterized (Hayward et al., 2001; Hakola et al., 2003, 2006; Ruuskanen et al., 2005), in contrast to soil VOC fluxes. Wintertime atmospheric VOC concentrations and fluxes from the canopy (Hakola et al., 2003, 2009; Lappalainen et al., 2009) are better known than those from soil, which are almost completely unstudied. VOC emissions from boreal forest soil are highest in the spring and autumn (Hellén et al., 2006; Aaltonen et al., 2011), but the processes behind the seasonal variations remain uncertain. However, most likely they are related to changes in biological activity in forest floor, for example increased decomposition. Since the soil surface is covered by snow during a substantial part of the year in the boreal zone, we conducted terpenoid concentration measurements inside the snowpack. So far, only a few studies reporting measurements of snowpack gas concentrations have been published (e.g. Helmig et al., 2009a; Kos and Ariya, 2010; Ariya et al., 2011), and these studies have been focused mainly on VOCs other than terpenoids. Biogenic VOCs take part in air chemistry and are relevant also for climate change (Kulmala et al., 2000). In order to better understand the biological processes behind the VOC fluxes, and also their role in air chemistry in the troposphere we need better understanding of wintertime forest floor VOC exchange.

During the active growing season, the above- and belowground parts of plants, as well as the diverse and effective soil 
Table 1. Sampling dates, min-max range of air temperatures, snowpack depths and snow water equivalents during winters 2008-2009 and 2009-2010.

\begin{tabular}{lccc}
\hline Sampling dates & $\begin{array}{c}\text { Air temperature } \\
{ }^{\circ} \mathrm{C}\end{array}$ & $\begin{array}{c}\text { Snowpack } \\
\text { depth cm }\end{array}$ & $\begin{array}{c}\text { Snow water } \\
\text { equivalent mm }\end{array}$ \\
\hline 27 November 2008 & -3.7 to 4.0 & 8 & 12 \\
5 February 2009 & -5.8 to -3.3 & 17 & 34 \\
3 March 2009 & -6.4 to -1.3 & 27 & 63 \\
1 April 2009 & 0.3 to 5.5 & 25 & 67 \\
12 January 2010 & -10.8 to -4.5 & 29 & 39 \\
2 February 2010 & -8.4 to -8.0 & 35 & 57 \\
1 March 2010 & -1.4 to -0.3 & 53 & 110 \\
24 March 2010 & -2.3 to 2.3 & 55 & 142 \\
\hline
\end{tabular}

microbial populations maintained by the forest ecosystem are a source of forest floor and soil VOCs (Janson, 1993; Hayward et al., 2001; Asensio et al., 2008; Leff and Fierer, 2008; Bäck et al., 2010). In winter, biological contributions to these fluxes, such as seasonal activity of plants, change due to limiting environmental factors and, most importantly, temperature and light availability. Root exudation plays a major role in the forest carbon cycle. Mycorrhizal hyphae, which are important contributors to decomposition of soil organic matter, are largely dependent on recent photosynthates emitted from the roots (Högberg et al., 2008). Mycorrhizal fungi emit substantial amounts of VOCs, the amount and quality being highly species-specific (Bäck et al., 2010). In late autumn and in winter when the photosynthesis of the trees is low, the lack of easily available energy sources (root exudates) may also decrease the decomposing activity in the soil, but most likely temperature is the overwhelming factor that affects the activity of decomposing organisms in the soil (Davidson and Janssens, 2006; Pumpanen et al., 2008; Schindlbacher et al., 2008; Vesala et al., 2010). In addition to VOC sources in the soil, microbes living inside and on the snowpack may produce VOCs, but could also act as sinks for them (Helmig et al., 2009a; Ariya et al., 2011).

In boreal areas, leaf turnover is an important process involved in winter tolerance and nutrient retranslocation from older to younger needles. In deciduous species, leaf fall is regulated by light availability and temperature, inducing senescence in a rather limited period of time in autumn. For evergreen foliage, the litterfall occurs in a less specific time. VOCs from fallen needles and other litter may be released during winter as a result of decomposition and physical degradation. Due to freezing and thawing cycles, the physical breakdown/degradation of litter is more important during winter than other seasons.

Chamber techniques have traditionally been applied for measurements of forest floor VOC fluxes and for other greenhouse gases as well. However, difficulties caused by low wintertime VOC fluxes and fluxes passing the chamber due to the high porosity of snow complicate the use of chambers for snowpack VOC flux measurements. Thus, we applied a gra- dient method for measurements, with custom-made samplers collecting air samples from three levels within the snowpack. This method is optimal for low fluxes, causing a smaller disturbance for the gases measured, and the flux calculation is based on concentration differences between the sampling layers. The gradient method also has some disadvantages, such as the need for additional information on environmental variables (e.g. temperature, humidity/moisture, porosity of the media) and its sensitivity to diffusivity of the target compound(s), especially when the diffusion coefficients for many compounds are poorly available and difficult to determine (Pumpanen et al., 2009).

We measured the concentrations of terpenoids inside the snowpack in a boreal forest during two subsequent winters. With these measurements, we wanted to improve our estimates of the importance of the winter season to annual VOC emissions in a boreal forest ecosystem. We assumed that the biologically active surface soil produces higher snowpack VOC concentrations close to the soil and that the formation of VOCs is dependent on soil temperature, the driving force of soil biological activity. Based on the concentrations of terpenoids inside the snowpack, we estimated the fluxes of these gases in the snowpack between the soil and the atmosphere.

\section{Methods}

\subsection{Measurement site}

We measured the snowpack VOC concentrations from a Scots pine (Pinus sylvestris L.) forest at the SMEAR II (Station for Measuring Forest Ecosystem-Atmosphere Relations II) station $\left(61^{\circ} 51^{\prime} \mathrm{N}, 24^{\circ} 17^{\prime} \mathrm{E}, 180 \mathrm{~m}\right.$ above sea level), located in the vicinity of the Hyytiälä Forestry Field Station in southern Finland (Hari and Kulmala, 2005). The forest stand at the SMEAR II station is 46 years old and dominated by Scots pine ( $>60 \%$ of the trees); some Norway spruce (Picea abies (L.) H. Karst.), aspen (Populus tremula L.) and birch (Betula L. spp.) also grow in the forest. The stand height is $\sim 18 \mathrm{~m}$ and the canopy is open, with an average tree density of $\sim 1370$ stems (diameter-at-breast height $\geq 5 \mathrm{~cm}$ ) per hectare (Ilvesniemi et al., 2009). The soil above the homogeneous bedrock is Haplic podzol in glacial till, with an average depth of $0.5-0.7 \mathrm{~m}$.

\subsection{VOC profile measurements}

We performed the snowpack VOC profile measurements during winters 2008-2009 and 2009-2010 (Table 1), in periods when the soil was covered approximately by at least $10 \mathrm{~cm}$ of snow. The VOC concentrations were measured from three permanently installed gas profile collectors consisting of three partially perforated circular polytetrafluoroethylene (PTFE) tubes (collector), where the lowest tube was placed at the ground, the middle tube at a height of 10 $15 \mathrm{~cm}$, while the uppermost one was $20 \mathrm{~cm}$ higher than the 


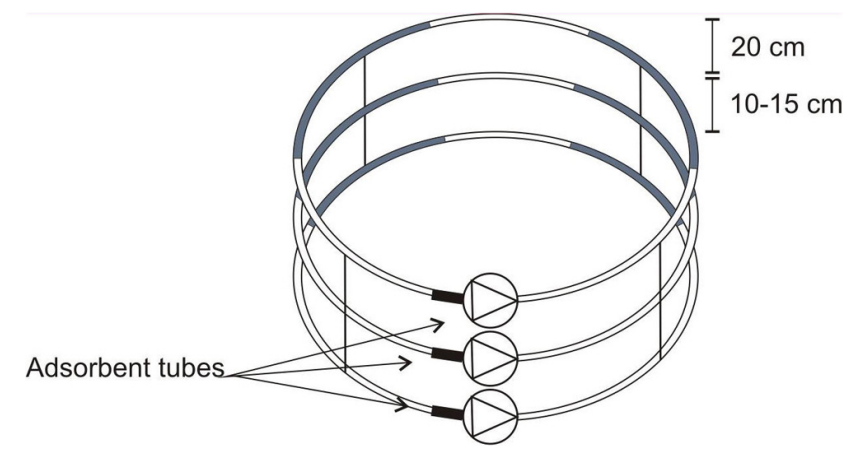

Fig. 1. Schematic figure of VOC snow profile. Grey areas represent perforated sectors.

middle tube. The PTFE tubes were $4 \mathrm{~m}$ long, with a $10-\mathrm{mm}$ outer diameter and 1-mm wall thickness. The central part had two $0.7-\mathrm{m}$-long sectors with perforation, and both ends and the middle sector were without perforation (Fig. 1). To minimize the disturbances caused by the bracing of the collectors and the installation of the pumps and adsorbent tubes, the collectors were partly imperforated. Chemically inert PTFE was chosen for the material of the collectors to avoid surface reactions deleterious to sample quality. Tubes up to $10 \mathrm{~m}$ long were tested in laboratory conditions to estimate wall losses, but no losses were detected. Test in field conditions below zero temperatures were not conducted. The tubes were installed at selected heights with thin wires $(\varnothing 2 \mathrm{~mm})$ to minimize the heating of dark surfaces by sunlight.

Samples were collected by circulating air from the collectors through a Tenax-Carbopack-B adsorbent tube at a flow rate of $\sim 100 \mathrm{ml} \mathrm{min}^{-1}$, using portable pumps. The adsorbent tube was connected to the collector and pump with Swagelok fittings with Teflon ferrules. The sampling flow through the adsorbent tube was measured each time prior and after the sampling for determination of the sampled air volume. Between samplings, both ends of the PTFE tubes were closed. During summer 2009, the collectors were removed from the field, but reinstalled at the same positions in autumn before the first snowfall.

Samplings were performed at approximately monthly intervals, each time consisting of four 15-min sampling periods (60 min total), with 15-min gaps between them. The amount of VOCs in the air volume inside the collector $(\sim 0.21)$ alone would not have been sufficient for GC-MS analysis; thus, in order to get a sufficient sample volume the air samplings were prolonged to $60 \mathrm{~min}$. The samplings were divided into four periods to equilibrate the VOC concentrations between the collector and the surrounding snow. Based on the diffusion rate of the VOCs in the air and in the snowpack, we estimated the minimum equilibrium time to be approximately 2 min, after which the air in the collector represented the air in the snowpack around the collector. The flow rate of the air circulation and the volume of the collector resulted in a residence time of the air in the collector of about $2 \mathrm{~min}$. The sampled area around the collectors (i.e. the source area of the collected VOCs) depends largely on snow properties, and close to the snowpack surface, on wind speed. Thus it was not possible to estimate the sampling volume exactly. However, we assume that the long sampling period and equilibration time as well as the large surface area of the collector, enable representative sampling of VOCs from the snow pack.

The samples in the adsorbent tubes were analysed in the laboratory, using a thermodesorption instrument (PerkinElmer TurboMatrix 650; PerkinElmer, Waltham, MA, USA) attached to a gas-chromatograph (Perkin-Elmer Clarus 600) with a mass-selective detector (Perkin-Elmer Clarus 600T). The sample tubes were desorbed at $300^{\circ} \mathrm{C}$ for $5 \mathrm{~min}$, cryofocused in a Tenax cold trap $\left(-30^{\circ} \mathrm{C}\right)$ prior to injecting the analytes into the column by rapidly heating the cold trap $\left(40^{\circ} \mathrm{C} \mathrm{min}-1\right)$ to $300^{\circ} \mathrm{C}$. The mass detector used enables simultaneous full scan and singular ion monitoring. Fivepoint calibration standards in methanol solutions were used. The standards were injected into the sampling tubes and the methanol was flushed away before the analysis. The analytical variability was determined using replicate standard analysis. The detection limits varied from $0.04 \mathrm{ng}$ to $0.60 \mathrm{ng}$ per tube and the overall uncertainties of sampling and analysis, calculated from parallel samples, were $12 \%, 10-40 \%$ and $33-52 \%$ for isoprene, monoterpenes and sesquiterpenes, respectively.

\subsection{Supporting data}

Snow depth was measured at weekly intervals at seven points, starting from the first snowfall and ending after the snowpack was completely melted. The snow water equivalent was measured every second week from the same points for estimating the diffusivity of the snowpack. Since the snow water content was measured for the full snowpack only, we used the SNOWPACK model to estimate the snow diffusivity and porosity throughout the snowpack during the VOC measurements. SNOWPACK is a one-dimensional model for snowpack structure, mass and energy balance, developed at the Swiss Federal Institute for Snow and Avalanche Research (SLF) for avalanche-warning purposes. The model used above canopy measurements of temperature, relative humidity, radiation (short + long wave), wind speed and direction, and precipitation as input data. Also canopy properties (e.g. leaf area index) and snowpack depth were needed. SNOWPACK is a predictive model that uses Lagrangian finite elements to solve heat and mass transfer as well as, stresses and strains within the snow cover. The model is physically based: energy balance, mass balance, phase changes, water and water vapour movement are included, and the layer calculations are based on snow microstructure (crystal size and form, bond size, number of bonds per crystal). A complete description of the model can be found in Bartelt and Lehning (2002) and Lehning et al. (2002a, b). The SNOWPACK 
model has been validated for the SMEAR II stand (Rasmus et al., 2007) as well as for several other sites under varying climatic conditions (e.g. Lehning et al., 1998; Lundy et al., 2001).

Air and humus layer temperatures (PT-100 resistance thermometer) and air-pressure data (Pressure Indicator DPI 260, Druck Ltd, Leicester, UK) were needed for flux calculations; the data were provided by the SMEAR II station (Hari and Kulmala, 2005). The humus layer temperatures were used for estimating the biological activity of the soil.

During the second winter of measurements (2009-2010), heavy snow loads caused substantial forest damages by breaking treetops and branches, as well as by felling whole trees. In spring 2010, the damages (more specifically, species composition, stem volume and basal area-at-breast height of the damaged trees) at the SMEAR II area were measured.

\subsection{Flux calculations}

For calculation of the VOC fluxes, based on the profile concentration measurements, we used Fick's law of diffusion as follows:

$$
F=-D\left(\frac{\delta C}{\delta z}\right)
$$

where $F$ is the gas flux $\left(\mathrm{ng} \mathrm{m}^{-2} \mathrm{~h}^{-1}\right), D$ is the compound specific diffusivity in air $\left(\mathrm{m}^{2} \mathrm{~h}^{-1}\right), \delta C$ the difference in gas concentrations $\left(\mathrm{ng} \mathrm{m}^{-3}\right)$ and $\delta z$ the distance $(\mathrm{m})$ between adjacent collectors. The diffusivity, taking into account the properties of porous media, was estimated by

$D=\phi \tau D_{0}\left(\frac{P_{0}}{P}\right)\left(\frac{T}{T_{0}}\right)^{1.75}$

modified from Seok et al. (2009), using a uniform temperature exponent (1.75) with Eq. (5). $\varphi$ is the snowpack porosity and $\tau$ the tortuosity, $D_{0}$ is the compound specific diffusivity for a reference pressure $\left(P_{0}=1013.3 \mathrm{hPa}\right)$ and temperature $\left(T_{0}=273.15 \mathrm{~K}\right)$, which is scaled to the ambient pressure $(P)$ and temperature $(T)$. Since we had temperature measurements of the air and humus layer, the temperature values for the snow profile were interpolated assuming that these measurements represent the temperature at the top and at the bottom of the snowpack. Using the SNOWPACK model, we validated this method for calculating the profile temperatures by assuming that the change was linear inside the snowpack, which showed good agreement, except for sunny spring days. The fixed temperature exponent 1.75 is a theoretically determined coefficient used also for calculations of diffusion coefficients (Fuller et al., 1969).

Snowpack porosity $(\varphi)$ was calculated by the equation

$\phi=1-\left(h_{\mathrm{w}} / 0.917 / h_{\mathrm{s}}\right)$,

where $h_{\mathrm{w}}$ is the snow water equivalent (m), $h_{\mathrm{s}}$ the snowpack depth $(\mathrm{m})$ and 0.917 describes the relationship between the densities of ice and water. Tortuosity $(\tau)$ is calculated from porosity according to Duplessis and Masliyah (1991) by the equation

$\tau=\frac{1-(1-\phi)^{\frac{2}{3}}}{\phi}$.

In this study the tortuosity is defined as a proportion of porosity, thus gaining values between 0 and 1 , with a value $1 \mathrm{im}$ plying no tortuosity (Duplessis and Masliyah, 1991). Experimentally determined diffusion coefficients for terpenoids are seldom available. Helmig et al. (2003) determined the diffusion coefficients for some sesquiterpenes, but for monoterpenes only some theoretical estimates are available (van Roon et al., 2005). Thus, we estimated the diffusion coefficients by the equation originally formed by Fuller et al. (1969) and modified by Poling et al. (2000) as follows:

$$
D_{\mathrm{AB}}=\frac{0.00143 T^{1.75}}{P\left\{2\left[\left(\frac{1}{M_{\mathrm{A}}}\right)+\left(\frac{1}{M_{\mathrm{B}}}\right)\right]^{-1}\right\}\left[\left(\Sigma_{\mathrm{v}}\right)_{\mathrm{A}}^{\frac{1}{3}}+\left(\Sigma_{\mathrm{v}}\right)_{\mathrm{B}}^{\frac{1}{3}}\right]^{2}},
$$

where $D_{\mathrm{AB}}$ is a binary diffusion coefficient (i.e. coefficient for chemical multi-component diffusion) $\left(\mathrm{cm}^{2} \mathrm{~s}^{-1}\right), T$ temperature (K), $P$ pressure (bar), $M_{\mathrm{A}}$ and $M_{\mathrm{B}}$ molecular weights of compounds A and B $\left(\mathrm{g} \mathrm{mol}^{-1}\right) . \Sigma_{\mathrm{v}}$ represents the summed atomic/molecular diffusion volumes, which were 15.9 for carbon, 2.31 for hydrogen and 19.7 for air (Fuller et al., 1969). Many of the mono- and sesquiterpenes contain one or more rings in their molecular structure, but Fuller et al. (1969) have determined only the effects of aromatic and heterocyclic rings on diffusivity (structural diffusion volume -18.3 for both of these ring structures), ignoring all other types of ring structures. Thus, we subtracted 18.3 once from the summed diffusion volumes to describe the diffusivity of mono- and sesquiterpenes more precisely. The compounds within the monoterpene group are isomeric, as are those within the sesquiterpenes, and the diffusion volumes of the various isomeric forms are equal. Thus we got the diffusion volume 177.66 for monoterpenes and 275.64 for sesquiterpenes. It is possible that the VOCs undergo chemical reactions inside the snowpack before they reach the snow surface, but since these reactions are poorly known, we could not implement them in the calculations. For further calculations the unit of $D_{\mathrm{AB}}$ was converted as $\mathrm{m}^{2} \mathrm{~h}^{-1}$.

\section{Results}

\subsection{Environmental conditions}

The air temperatures of these two sampling winters (1 November-30 April) differed greatly at the SMEAR II station (Fig. 2). In 2008-2009, except for a cold period in late March, the temperatures were always higher than the 30-year 

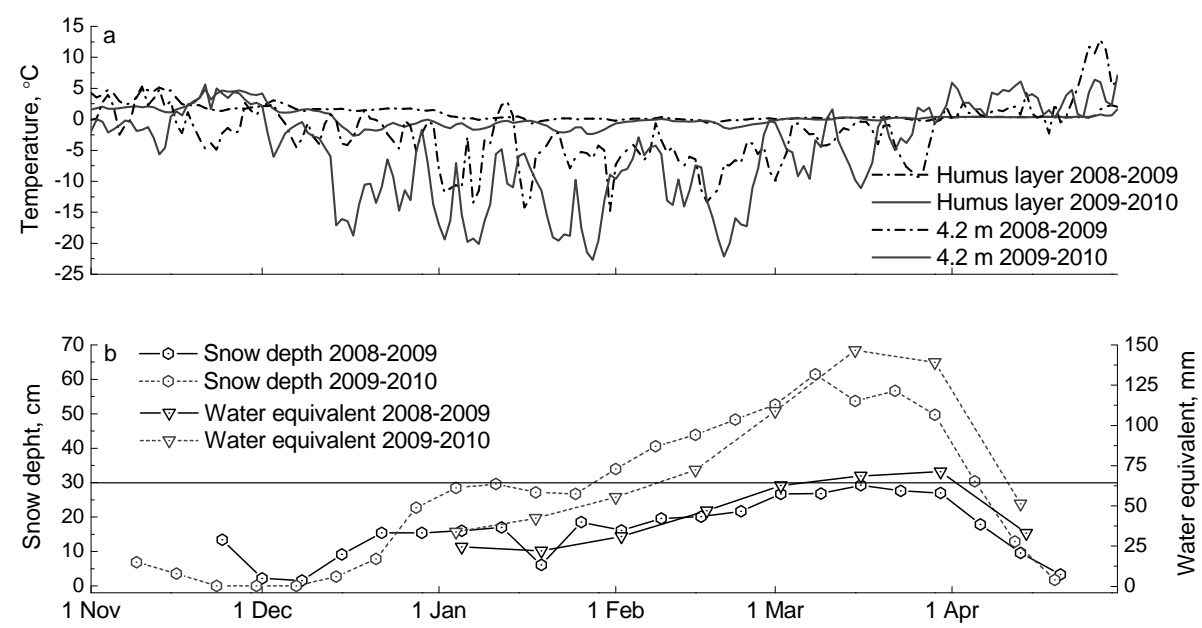

Fig. 2. Temperature, snow depth and water equivalent at the SMEAR II station during winters 2008-2009 and 2009-2010. (a) temperature in humus layer and at 4.2-m height, (b) snow depth and water equivalent. Horizontal line in panel (b) shows the height of the uppermost collectors.
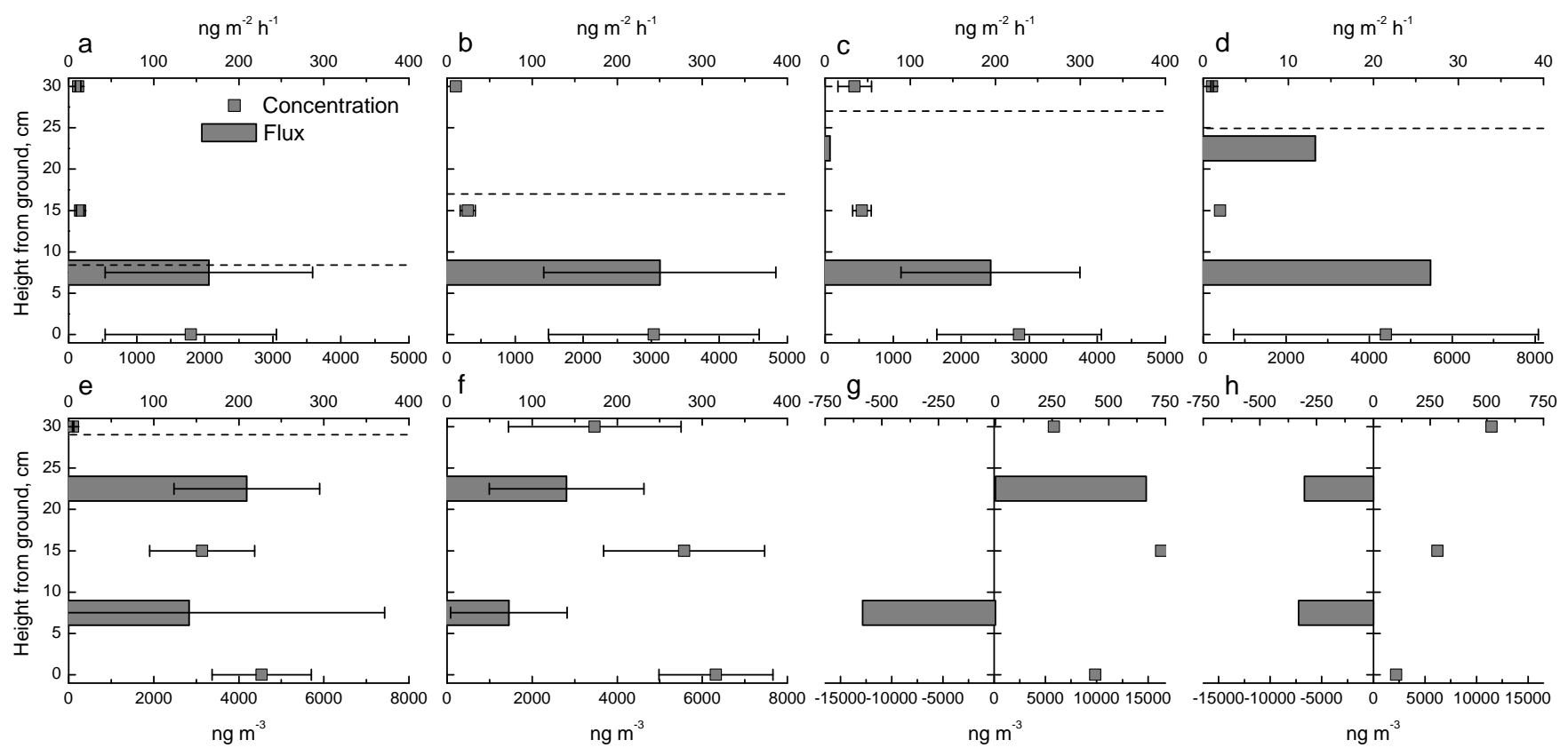

Fig. 3. Total monoterpene concentrations and estimated fluxes in the snowpack during sampling dates (a) 27 November 2008 , (b) 5 February 2009, (c) 3 March 2009, (d) 1 April 2009, (e) 12 January 2010, (f) 2 February 2010, (g) 1 March 2010 and (h) 24 March 2010. Error bars (if more than two values) represent standard error of the tree collectors. $0 \mathrm{~cm}$ represents the soil surface and dashed horizontal line the snowpack depth, if it was below $30 \mathrm{~cm}$. Data of two damaged profiles were omitted from sampling days 2 February 2010 and 1 March 2010.

average, which is $-4^{\circ} \mathrm{C}$ for period 1 November-30 April and $-6.9^{\circ} \mathrm{C}$ for the winter months (Drebs et al., 2002). However, throughout the following midwinter 2009-2010 the temperatures were notably lower than the average. Exceptionally, the air temperatures in winter 2009-2010 were continuously below zero for over 3 months, beginning from the early December. The difference between winters was also wide in the humus layer temperatures. During the first winter, the temperature was above zero most of the time, dropping below zero only occasionally, whereas in winter 2009-2010 humus temperatures were below zero continuously from mid-December to early March (Fig. 2). In the latter winter, the humus temperatures were close to $-3{ }^{\circ} \mathrm{C}$, while in the first winter they never dropped even below $-1{ }^{\circ} \mathrm{C}$.

These two winters also differed regarding the amount of snow (Fig. 2). During winter 2008-2009 the snow depth was throughout the winter clearly below the 30 -year average (Drebs et al., 2002), while in winter 2009-2010 it was 

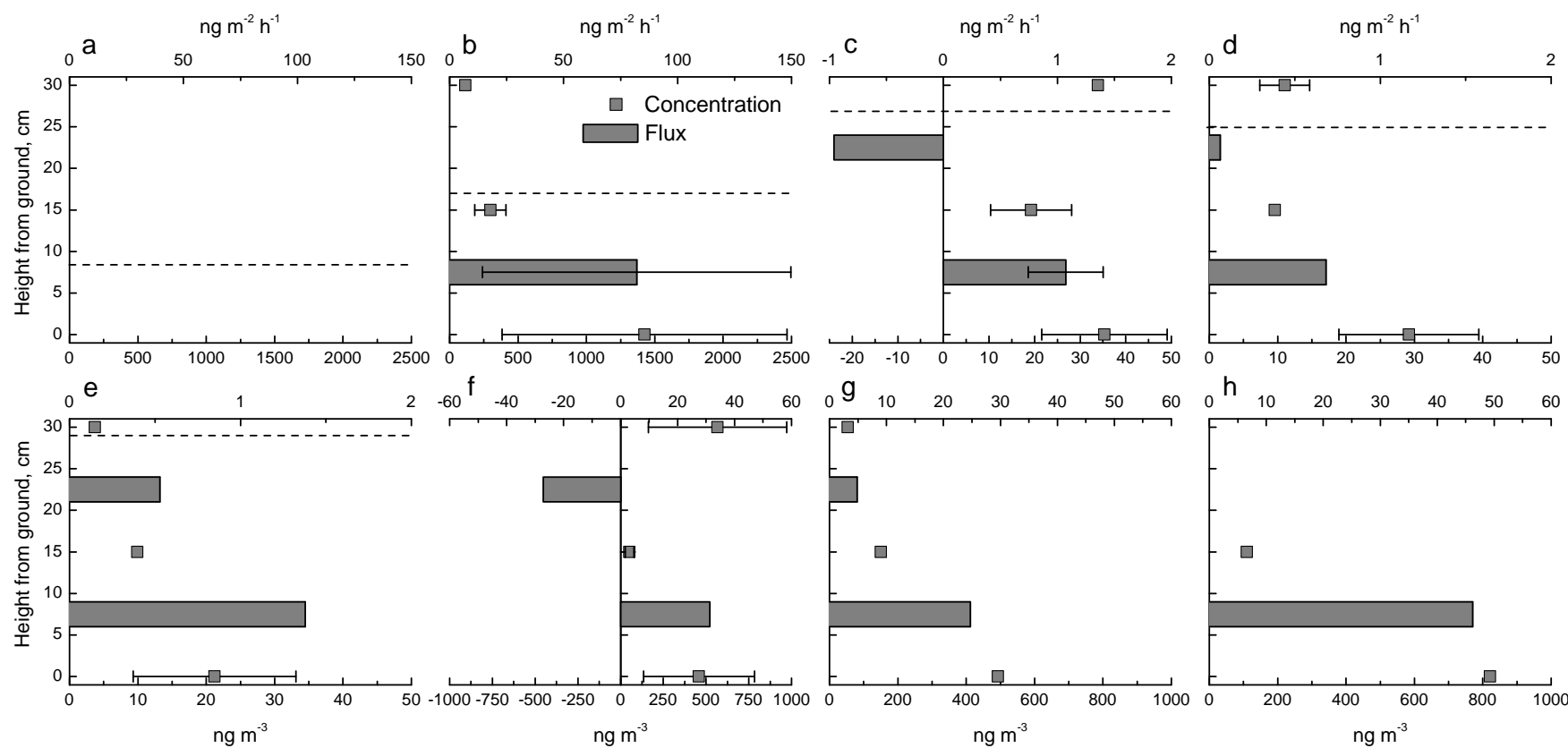

Fig. 4. Total sesquiterpene concentrations and estimated fluxes in the snowpack during sampling dates (a) 27 November 2008 , (b) 5 February 2009, (c) 3 March 2009, (d) 1 April 2009, (e) 12 January 2010, (f) 2 February 2010, (g) 1 March 2010 and (h) 24 March 2010. Error bars (if more than two values) represent standard error of the tree collectors. $0 \mathrm{~cm}$ represents the soil surface and dashed horizontal line the snowpack depth, if it was below $30 \mathrm{~cm}$. Data of two damaged profiles were omitted from sampling days 2 February 2010 and 1 March 2010.

very close to the average. In winter 2008-2009, the uppermost profile collectors were during the time of the thickest snowpack only barely covered by snow, the average maximum snowpack thickness of the 30 -year period being $47 \mathrm{~cm}$ (Drebs et al., 2002). The depth of the snow in winter 20092010 was approximately twice that in the previous winter, being $\sim 60 \mathrm{~cm}$ at maximum. The maximum depth in FebruaryMarch was slightly above the average, but at the beginning and end of the snow cover period, the snow depth was lower than the average. The water equivalent of snow was also over two-fold higher in 2009-2010 than in 2008-2009, being $\sim 10 \%$ of the snow depth during both winters.

During the forest damages in winter 2009-2010, approximately $12 \%$ of the trees fell at the SMEAR II stand, and practically all of these ( $>99 \%$ ) were Scots pines. In addition to fallen trees, a large unmeasured volume of different sizes of branches and needles dropped on and inside the snowpack.

\subsection{Snowpack VOC concentrations}

We detected 20 different biogenic VOCs from the snowpack, including 11 monoterpenes and oxygen-containing monoterpenes, 7 sesquiterpenes and 2 hemiterpenoids (Table 2). The most abundant VOC group was monoterpenes. The average monoterpene concentrations (used also for flux estimations) varied from 0.13 to $4.4 \mu \mathrm{g} \mathrm{m}^{-3}$ during the first winter and from 0.11 to $16 \mu \mathrm{g} \mathrm{m}^{-3}$ during the second winter (Fig. 3). The concentration data from two profiles damaged during the forest damages in the second winter were omit- ted from these averages. $\Delta^{3}$-carene and $\alpha$-pinene were the predominant compounds, followed by $\beta$-pinene, terpinolene, limonene and camphene. During the first winter, $\alpha$-pinene had the highest concentrations, but in the middle of the second winter, $\Delta^{3}$-carene clearly predominated. The average sesquiterpene concentrations were generally less than half of the monoterpene concentrations (Fig. 4), $1.4 \mu \mathrm{g} \mathrm{m}^{-3}$ being the highest concentration in the first winter and $0.82 \mu \mathrm{g} \mathrm{m}^{-3}$ in the second. Occasionally, the sesquiterpene concentrations were close to detection limit, but on the first measurement day 27 November 2008 no sesquiterpenes were found. Isoprene was detected in the first samplings of both winters, but its concentrations were negligible, reaching $0.40 \mu \mathrm{g} \mathrm{m}^{-3}$ at maximum (Table 2).

During the first winter and the first two months of the second winter, the monoterpene concentrations were clearly highest at the ground level and decreased rapidly towards the snow surface (Fig. 3). During the latter half of the second winter, the vertical distribution of monoterpene concentrations was reversed in two out of the three profiles, i.e. the concentrations of monoterpenes were highest near the snow surface. With sesquiterpenes, the trend of decreasing concentrations towards the snow surface persisted more or less throughout the measurement period (Fig. 4). At the end of the second winter, monoterpene concentrations, especially $\beta$-pinene, $\Delta^{3}$-carene and terpinolene, increased dramatically (from 1000- up to 1700-fold) in these two profiles. With other monoterpenes, the increase varied from 10 - to 200 -fold and 
Table 2. Average concentrations of the terpenoids observed in different snowpack profiles $(n=3)$ during winters 2008-2009 and 2009-2010, $0 \mathrm{~cm}$ representing the soil surface.

\begin{tabular}{|c|c|c|c|c|c|c|}
\hline \multirow[b]{2}{*}{$n g m^{-3}$} & \multicolumn{3}{|c|}{ 2008-2009 } & \multicolumn{3}{|c|}{$2009-2010$} \\
\hline & $0 \mathrm{~cm}$ & $15 \mathrm{~cm}$ & $30 \mathrm{~cm}$ & $0 \mathrm{~cm}$ & $15 \mathrm{~cm}$ & $30 \mathrm{~cm}$ \\
\hline \multicolumn{7}{|l|}{ Hemiterpenoids } \\
\hline isoprene & 82 & 24 & 11 & 17 & 400 & 12 \\
\hline methyl butenol & 20 & 10 & 110 & 13 & 15 & 13 \\
\hline \multicolumn{7}{|l|}{ Monoterpenes } \\
\hline$\alpha$-pinene & 1700 & 130 & 74 & 2800 & 2800 & 1400 \\
\hline$\beta$-pinene & 35 & 6.0 & 18 & 140 & 210 & 190 \\
\hline bornylacetate & 130 & 40 & 24 & 93 & 29 & 78 \\
\hline camphene & 550 & 49 & 15 & 640 & 530 & 200 \\
\hline$\Delta^{3}$-carene & 660 & 85 & 39 & 1900 & 2300 & 1400 \\
\hline limonene & 74 & 75 & 63 & 80 & 190 & 320 \\
\hline linalool & 9.3 & & & 20 & & 25 \\
\hline nopinone & 9.4 & 9.0 & 12 & 8.8 & 19 & 21 \\
\hline p-cymene & 12 & 7.7 & 9.5 & 23 & 30 & 33 \\
\hline terpinolene & 41 & 6.5 & 9.2 & 26 & 64 & 50 \\
\hline 1,8-cineol & 2.3 & 3.6 & 34 & & 7.6 & 12 \\
\hline Total monoterpenes & 3224 & 412 & 299 & 5731 & 6180 & 3728 \\
\hline \multicolumn{7}{|l|}{ Sesquiterpenes } \\
\hline$\alpha$-humulene & 72 & 42 & 21 & 100 & 11 & 120 \\
\hline alloaromadendrene/farnesene & 73 & 27 & 16 & 75 & 12 & 71 \\
\hline aromadendrene & 140 & 25 & 14 & 89 & 7.1 & 90 \\
\hline$\beta$-caryophyllene & 87 & 24 & 17 & 93 & 35 & 54 \\
\hline iso-longifolene & 100 & 25 & 5.5 & 96 & 7.6 & 62 \\
\hline longicyclene & 69 & 19 & 9.5 & 74 & 11 & 71 \\
\hline longifolene & 480 & 100 & 25 & & & \\
\hline Total sesquiterpenes & 1021 & 262 & 108 & 527 & 84 & 467 \\
\hline
\end{tabular}

with sesquiterpenes the increase in concentrations was approximately 10 -fold.

The monoterpene concentrations in the lowest collectors were on average about 10-fold higher (5.3-11) than in the middle collector throughout the first winter, but in the second winter the ratio between these decreased to approximately $1(0.36-1.5)$. However, for the sesquiterpenes the ratio was similar in both winters (1.8-8.8).

\subsection{Wintertime fluxes of VOCs}

Based on our measurements of VOC concentrations in the snowpack profiles, we estimated the wintertime forest floor VOC fluxes. The snowpack in winter 2008-2009 was rather shallow. Snow did not fully cover the topmost collector during any measurement time and was even less than $20 \mathrm{~cm}$ thick during the first two measurements. Therefore, for the first two measurement times we calculated fluxes only from the ground level to the middle collector and for the two latter times the flux values from the middle to the topmost collectors were merely indicative. Since the diffusion calculation (Eq. 1) was parameterized for snow and it did not take into account convective transport, it was not meaningful to estimate the transport in air. The forest damages in midwinter 2009-2010 destroyed the structure of two out of three profiles (those with the high terpenoid concentrations), thus from the last two measurements we obtained the concentration data for the flux calculations from one plot only.

The monoterpene fluxes from the ground level to the middle of the profile varied from 10 to $490 \mathrm{ng} \mathrm{m}^{-2} \mathrm{~h}^{-1}$ during winter 2008-2009 (Fig. 3), but the fluxes from the middle to the top profile were very low $\left(26 \mathrm{ng} \mathrm{m}^{-2} \mathrm{~h}^{-1}\right.$ at maximum). During the second winter, negative fluxes were also observed, the values ranging from -580 to $590 \mathrm{ng} \mathrm{m}^{-2} \mathrm{~h}^{-1}$ for the lower level and from -300 to $670 \mathrm{ng} \mathrm{m}^{-2} \mathrm{~h}^{-1}$ for the upper level. The sesquiterpene concentrations were clearly lower than those of monoterpenes, as were also the sesquiterpene fluxes (Fig. 4). In the first winter, fluxes from the ground to the middle of the snow profile varied between 0.19 and $22 \mathrm{ng} \mathrm{m}^{-2} \mathrm{~h}^{-1}$, except for one plot on 5 February 2009, when the flux was exceptionally high, $220 \mathrm{ng} \mathrm{m}^{-2} \mathrm{~h}^{-1}$. Fluxes from the middle of the profile to the top were practically zero $\left(-0.96-0.08 \mathrm{ng} \mathrm{m}^{-2} \mathrm{~h}^{-1}\right)$. During the second winter, fluxes 
were $-0.36-83 \mathrm{ng} \mathrm{m}^{-2} \mathrm{~h}^{-1}$ from the soil surface to the collector in the middle of the profile and $-71-4.9 \mathrm{ng} \mathrm{m}^{-2} \mathrm{~h}^{-1}$ from the middle to the topmost collector.

\section{Discussion}

\subsection{VOC concentrations}

The snowpack VOC concentrations closer to the soil surface were usually higher than those of the snow-atmosphere interface. During the first measurement winter this phenomenon was clear, but not during the second winter. Nor was the assumed linkage between soil temperature, associated with soil biological activity, and wintertime biogenic VOC emissions evident. During the latter, colder winter, the snowpack VOC concentrations were always higher, even before the forest damages incurred by the snow load.

When these snowpack VOC concentrations were compared with our belowground VOC measurements (unpublished data) conducted during the snow-free period, the magnitudes, excluding the exceptionally high concentration inside the snowpack during late winter 2009-2010, were equal. Snowpack concentrations of monoterpenes at the SMEAR II were of the same order of magnitude as the above-canopy monoterpene concentrations measured in winter- and summertime (Hakola et al., 2003, 2009). Such high concentrations suggest an accumulation of monoterpenes below and inside the snowpack. Also the presumably low amount of oxidants (see Sect. 4.2) inside the snowpack favours the accumulation of terpenoids. This result emphasizes the importance of the snow cover period for the annual forest floor VOC emissions as well as the role of soil as a VOC source also in wintertime, when other biological sources are less active. The Scots pine branch monoterpene emissions peak in early spring and midsummer and are minimal during the midwinter period, whereas the sesquiterpenes are only seen during midsummer in the branch emissions (Tarvainen et al., 2005; Hakola et al., 2006). Pine emissions consist of several compounds, but the most common ones are $\alpha$-pinene and $\Delta^{3}$ carene. They were the two most abundant monoterpenes in this study and our summertime measurements on soil at the same site as well (Aaltonen et al., 2011). Both of these compounds have carbon-carbon double bonds and thus form secondary organic aerosols by reactions with ozone $\left(\mathrm{O}_{3}\right)$ (Hatfield et al., 2011). Some other monoterpenes (e.g. limonene) and the sesquiterpenes we observed are more susceptible to oxidation by $\mathrm{O}_{3}$, but their concentrations were in general very low. However, $\mathrm{O}_{3}$ concentrations inside the snowpack are generally very low (see Sect. 4.2) and thus the high reactivity of terpenoids is mainly realized after the compounds are released to the atmosphere.

In our measurements, the terpenoid concentrations often decreased quickly towards the snow surface, a phenomenon also evident in the snow profile VOC measurements done by Helmig et al. (2009a) for compounds originating from the soil. The terpenoid concentrations in the air were often clearly lower than the concentrations inside the snowpack. The sharply dropping concentrations close to the snow surface were probably due to the different diffusion constants of the snow surface and the air, resulting in more efficient transport between the snow and air close to the snow surface than in the deeper layers.

\subsection{Sources and sinks of snowpack VOCs}

The clearly decreasing VOC concentrations from the ground level towards the snow surface during most of the measurement periods suggest that the VOC source was located either below ground or on the soil surface (litter). One probable source of the VOCs is the active decomposition below the snowpack, which is supported by the finding of Kähkönen et al. (2001) that the decomposition is not completely ceased even at below-zero temperatures. Bowling et al. (2009) also found clear evidence of microbial activity below the snowpack by measuring similar stable carbon isotope compositions $\left(\delta^{13} \mathrm{C}\right)$ of soil respiration during winter and summer. Some terpenoids, however, showed contrasting trends in concentrations, i.e. the concentrations were always higher in the upper snow layers. Compounds having clearly the highest concentrations in the uppermost collector included 1,8-cineol and linalool, which emissions are strongly light-dependent and thus supposed to originate from photosynthetic tissues (Staudt et al., 1997; Tarvainen et al., 2005). Another example of compounds with a top-to-bottom flux is nopinone, which is an oxidation product of $\beta$-pinene (Holzinger et al., 2005). The chemical reactions that the terpenoids undergo inside the snowpack are difficult to estimate due to the poorly known oxidant levels. $\mathrm{O}_{3}$ deposition to snow and concentrations inside the snowpack has been found to be low (Zeller and Hehn, 1995; Helmig et al., 2009b; Bocquet et al., 2011). OH concentrations may be higher under sunny conditions (Anastasio et al., 2007; Beyersdorf et al., 2007), however, light levels on boreal forest floor during winter are very low. Thus, for oxidative reactions the snow-air interface, including the top layers of the snowpack, seems to be more important than the deeper layers of the snowpack.

Snowpack concentrations of organic compounds are affected not only by soil-living microbes, but also by microbes living inside the snowpack. Several studies (e.g. Amato et al., 2007; Ariya et al., 2011) have reported various microbial groups and species living and actively functioning in snow. These microbes - algae, fungi and bacteria - may either produce or use VOCs, or affect the chemical reactions in which the VOCs participate. During winter and especially during spring, dissolved organic carbon (DOC) from trees accumulates inside and on the snowpack. DOC itself, as well as DOC decomposed by snow-living microbes, may act as notable sources of snowpack VOC fluxes in spring. However, this is a totally unidentified VOC source and needs further studies. 
Heavy snow loading at the end of the second winter caused extensive forest damage at the study site. Treetops, branches and needles, as did some pine tops fell partly or fully over two collectors. This was likely the reason for the dramatic increase in snow monoterpene concentrations observed in March 2010. Damaged parts of trees, especially needles and young branches, may emit high amounts of terpenoids from the abundant reservoirs in needles and woody tissue (Staudt et al., 1997; Ghirardo et al., 2010). Haapanala et al. (2012) measured clear increases in monoterpene emissions from stumps and logging residue after timber felling, while sesquiterpene and isoprene emissions remained at low levels, which supports our assumption of forest damages being the main reason for the dramatic increase in snowpack monoterpene concentrations in the second spring.

The proportions of different monoterpenes inside the snowpack changed concomitantly with the increased total concentrations, suggesting a sudden change in the VOC source, most probably from "normal" litter decomposition or biological sources in the soil to damaged tree organs. Most likely the additional VOCs originated from physical processes (crushing of the needles and branches and evaporation of easily volatile compounds from the plant tissue) and not from biological decomposition processes, which could not play such a significant role in winter when the temperature of the snowpack was almost constantly below $0{ }^{\circ} \mathrm{C}$. In the collector that was left undamaged, the magnitude of the concentrations remained similar as before. Concomitantly with the increase in VOC concentrations in the snowpack, the highest concentrations were no longer measured from the ground level, but instead in the middle or top collectors. In addition to the change in VOC source from soil to fallen tree litter, the profile structures may have been harmed by falling branches, i.e. it is possible that the collectors were shifted from their initially installed places closer to each other. Nevertheless, the concentrations in the damaged collectors were far above those measured from the soil surface (Aaltonen et al., 2011) or from inside the soil (unpublished data). Thus, inevitably the concentration increase after the snow damage can be traced to fallen branches and needles. This stresses the importance of occasional damage periods, such as windthrows, forestry operations and snow damage, to the stand-level VOC flux.

\subsection{VOC fluxes}

Since the monoterpene concentrations in ambient air (indicated by values from the topmost collectors which were above the snow surface) were quite low in winter 2008-2009, the fluxes were upwards throughout the season. The extensive forest damages in midwinter 2009-2010 apparently increased the monoterpene concentrations in the air over the SMEAR II forest, and in the last two measurements the snowpack may have acted as a sink for these compounds. Since the sources of the various VOCs are unknown, it is dif- ficult to estimate whether the snow properties determine the partitioning and movements of some compounds more than others. However, sesquiterpene concentrations and estimated fluxes were less affected by the forest damages than those of monoterpenes. Moreover, in addition to the possible different sources of these compounds, the snow physical properties may have also played a role in this phenomenon.

For atmospheric chemistry the release of the VOCs from the snowpack into the atmosphere is more important than the flux from the forest floor to the snowpack or the fate of the VOCs inside the snowpack. Low VOC flux from the snowpack to the atmosphere occurs during the whole snow cover period, but measurements made by Hellén et al. (2006) and Aaltonen et al. (2011) suggest that the high VOC burst in spring probably originates from volatiles accumulated below and inside the snowpack. The wintertime monoterpene fluxes measured inside the pine forest snowpack at the SMEAR II station were on average at least one magnitude lower than those measured during a snow-free period with chambers (Aaltonen et al., 2011). The sesquiterpene fluxes measured from the snowpack were more or less similar to those measured by Aaltonen et al. (2011) during the snow-free time, however those fluxes are also low in summer. The summertime monoterpene emissions measured from Scots pine branches at the SMEAR II stand differed substantially between tree individuals (Bäck et al., 2012), but are one to two magnitudes higher than from snowpack (Bäck et al., 2005; Hakola et al., 2006, 2009). Data on wintertime VOC concentrations or fluxes over boreal Scots pine forest are scarce, but the results by Hakola et al. (2009), Lappalainen et al. (2009) and our unpublished results show rather low monoterpene concentrations and flux, comparable to those measured in this study between the snowpack and atmosphere. While the reactions of the VOCs inside the snowpack are poorly understood and thus omitted from our flux calculations, the calculated fluxes must be considered more as estimates than exact values. However, as discussed already in Sect. 4.2, the concentrations of the main oxidants, $\mathrm{OH}$ and $\mathrm{O}_{3}$, inside the snowpack are presumably low, except for the surface layer of the snowpack (Zeller and Hehn, 1995; Anastasio et al., 2007; Beyersdorf et al., 2007), as are the temperature and light levels, all of which reduce the reactivity of VOCs.

\subsection{Importance of snow physical properties}

The physical properties of snow may have substantial effects on diffusion of volatiles in the snowpack. The density of snow is one of the most important factors controlling gas transport in the snowpack (Seok et al., 2009) and fortunately it is quite easy to measure. Vertical movement of gases may be blocked by the ice layers formed by freezing after periods of above-zero temperatures. The second winter of our measurements included a long period with temperatures constantly below zero, and thus the snowpack presumably was mostly homogenous, soft snow. The SNOWPACK 
model runs resulted in over $50 \%$ air volume fractions for the snowpack during all measurement days in both winters and also for cases when the modelled snow grain type showed ice formation inside the snowpack. Thus, the ice layers would probably never have fully stopped the gas transport inside the snowpack during our measurements. However, possible thick ice layers inside the snowpack may have affected the distribution of gas fluxes by causing horizontal gas movements and the release of gases into the atmosphere through occasional holes, such as along tree trunks. Climate change is predicted to increase wintertime temperatures at high latitudes more than during other seasons, which could make the snow consistency less permeable. This type of change emphasizes the importance of springtime for forest floor VOC exchange (see Hellén et al., 2006; Aaltonen et al., 2011), because during and after snowmelt the blocked compounds are rapidly released. The spring peak in aerosol particle formation events (Dal Maso et al., 2005) will probably also increase, if the springtime VOC burst during snowmelt will become more intense.

The physical properties of the snowpack can also be affected by biological organisms. Ariya et al. (2011) observed that microbes living in the snow may significantly influence snow morphology by making cavities and thus increasing the specific snow surface area. The cavities Ariya et al. (2011) observed in snow crystals were $\sim 2 \mu \mathrm{m}$ in diameter and most probably made by fungal hyphae or by bacterial filaments. For reactive gases the increased specific snow surface area means further opportunities for chemical reactions.

\section{Conclusions}

Snowpacks in boreal pine forests contain substantial concentrations of terpenoids, especially monoterpenes. In a pristine snowpack, these concentrations decrease towards the snow surface, suggesting that soil is the source for terpenoids. While the activity of plant roots is low in winter, the most probable actual source is decomposition of litter. The hard winter during the measurement period caused substantial forest damage and changes in snowpack monoterpene concentrations and distributions. Both the radically increased monoterpene concentrations as well as the change observed in relative proportions of compounds suggest that the crushed needles and fallen branches and trees can act as strong sources, even when they are frozen. Even though biological and physical factors are difficult to separate, it is clear that physical properties of the snowpack play a role in the diffusion efficiency of gas fluxes.

This study shows that decomposition processes in the soil are active and form an efficient VOC source during winter and that natural or human disturbance can cause high VOC emissions from nonactive (decaying) biomass. Our results stress the importance of soil as a source of VOCs throughout the year, and especially during the season when the activities of other biological sources are low and the atmospheric lifetime of VOCs is extended. These new results of significant wintertime VOC emissions from forest floor emphasize their important role in ecosystem scale VOC fluxes, especially after a disturbance, and these results may be utilised to improve the ecosystem-level VOC emission models.

Acknowledgements. We thank the staff of the SMEAR II and Hyytiälä Forestry Field Station for help and for use of the facilities in this study. This project was financially supported by the Vilho, Yrjö and Kalle Väisälä Fund, by the Academy of Finland project 218094, by the Academy of Finland Centre of Excellence programme (project number 1118615) and by the Nordic Centre of Excellence programme CRAICC. Financial support by the EU projects NitroEurope and Infrastructure for Measurements of the European Carbon Cycle (IMECC) is also gratefully acknowledged.

Edited by: L. Ganzeveld

\section{References}

Aaltonen, H., Pumpanen, J., Pihlatie, M., Hakola, H., Hellén, H., Kulmala, L., Vesala, T., and Bäck, J.: Boreal pine forest floor biogenic volatile organic compound emissions peak in early summer and autumn, Agr. Forest Meteorol., 151, 682-691, 2011.

Amato, P., Hennebelle, R., Magand, O., Sancelme, M., Delort, A.M., Barbante, C., Boutron, C., and Ferrari, C.: Bacterial characterization of the snowcover at Spitzberg, Svalbard, FEMS Microbiol. Ecol., 59, 255-264, 2007.

Anastasio, C., Galbavy, E. S., Hutterli, M. A., Burkhart, J. F., and Friel, D. K.: Photoformation of hydroxyl radical on snow grains at Summit, Greenland, Atmos. Environ., 41, 5110-5121, 2007.

Ariya, P. A., Domine, F., Kos, G., Amyot, M., Côté, V., Vali, H., Lauzier, T., Kuhs, W. F., Techmer, K., Heinrichs, T., and Mortazavi, R.: Snow - a photobiochemical exchange platform for volatile and semi-volatile organic compounds with the atmosphere, Environ. Chem., 8, 62-73, 2011.

Asensio, D., Peñuelas, J., Prieto, P., Estiarte, M., Filella, I., and Llusià, J.: Interannual and seasonal changes in the soil exchange rates of monoterpenes and other VOCs in a Mediterranean shrubland, Eur. J. Soil Sci., 59, 878-891, 2008.

Bartelt, P. and Lehning, M.: A physical SNOWPACK model for the Swiss avalanche warning: Part I. Numerical model, Cold Reg. Sci. Technol., 35, 123-145, 2002.

Beyersdorf, A. J., Blake, N. J., Swanson, A. L., Meinardi, S., Dibb, J. E., Sjostedt, S., Huey, G., Lefer, B., Rowland, F, S., and Blake, D. R.: Hydroxyl concentration estimates in the sunlit snowpack at Summit, Greenland, Atmos. Environ., 41, 5101-5109, 2007.

Bocquet, F., Helmig, D., Van Dam, B. A., and Fairall, C. W.: Evaluation of the flux gradient technique for measurement of ozone surface fluxes over snowpack at Summit, Greenland, Atmos. Meas. Tech., 4, 2305-2321, doi:10.5194/amt-4-2305-2011, 2011.

Bowling, D. R., Massman, W. J., Schaeffer, S. M., Burns, S. P., Monson, R. K., and Williams, M. W.: Biological and physical influences on the carbon isotope content of $\mathrm{CO}_{2}$ in a subalpine forest snowpack, Niwot Ridge, Colorado, Biogeochemistry, 95, 37-59, 2009. 
Bäck, J., Hari, P., Hakola, H., Juurola, E., and Kulmala, M.: Dynamics of monoterpene emissions in Pinus sylvestris during early spring, Boreal Environ. Res., 10, 409-424, 2005.

Bäck, J., Aaltonen, H., Hellén, H., Kajos, M. K., Patokoski, J., Taipale, R., Pumpanen, J., and Heinonsalo, J.: Variable emissions of microbial volatile organic compounds (MVOCs) from root associated fungi isolated from Scots pine, Atmos. Environ., 44, 3651-3659, 2010.

Bäck, J., Aalto, J., Henriksson, M., Hakola, H., He, Q., and Boy, M.: Chemodiversity of a Scots pine stand and implications for terpene air concentrations, Biogeosciences, 9, 689-702, doi:10.5194/bg-9-689-2012, 2012.

Dal Maso, M., Kulmala, M., Riipinen, I., Wagner, R., Hussein, T., Aalto, P. P., and Lehtinen, K. E. J.: Formation and growth of fresh atmospheric aerosols: eight years of aerosol size distribution data from SMEAR II, Hyytiälä, Finland, Boreal Environ. Res., 10, 323-336, 2005

Davidson, E. A. and Janssens, I. A.: Temperature sensitivity of soil carbon decomposition and feedbacks to climate change, Nature, 440, 165-173, 2006.

Drebs, A., Nordlund, A., Karlsson, P., Helminen, J., and Rissanen, P.: Climatological Statistics of Finland 1971-2000, Finnish Meteorological Institute, Helsinki, Finland, 2002.

Duplessis, J. P. and Masliyah, J. H.: Flow through isotropic granular porous-media, Transport Porous Med., 6, 207-221, 1991.

Fuller, E. N., Ensley, K., and Giddings, J. C.: Diffusion of halogenated hydrocarbons in helium. The effect of structure on collision cross sections, J. Phys. Chem., 73, 3679-3685, 1969.

Ghirardo, A., Koch, K., Taipale, R., Zimmer, I., Schnitzler, J.-P., and Rinne, J.: Determination of de novo and pool emissions of terpenes from four common boreal/alpine trees by ${ }^{13} \mathrm{CO}_{2}$ labelling and PTR-MS analysis, Plant Cell Environ., 33, 781-792, 2010.

Haapanala, S., Hakola, H., Hellén, H., Vestenius, M., Levula, J., and Rinne, J.: Is forest management a significant source of monoterpenes into the boreal atmosphere?, Biogeosciences, 9, 12911300, doi:10.5194/bg-9-1291-2012, 2012.

Hakola, H., Tarvainen, V., Laurila, T., Hiltunen, V., Hellén, H., and Keronen, P.: Seasonal variation of VOC concentrations above a boreal coniferous forest, Atmos. Environ., 37, 1623-1634, 2003.

Hakola, H., Tarvainen, V., Bäck, J., Ranta, H., Bonn, B., Rinne, J., and Kulmala, M.: Seasonal variation of mono- and sesquiterpene emission rates of Scots pine, Biogeosciences, 3, 93-101, doi:10.5194/bg-3-93-2006, 2006.

Hakola, H., Hellén, H., Tarvainen, V., Bäck, J., Patokoski, J., and Rinne, J.: Annual variations of atmospheric VOC concentrations in a boreal forest, Boreal Environ. Res., 14, 722-730, 2009.

Hari, P. and Kulmala, M.: Station for Measuring EcosystemAtmosphere relations (SMEAR II), Boreal Environ. Res., 10, 315-322, 2005.

Hatfield, M. L. and Huff Hartz, K. E.: Secondary organic aerosol from biogenic volatile organic compound mixtures, Atmos. Environ., 45, 2211-2219, 2011.

Hayward, S., Muncey, R. J., James, A. E., Halsall, C. J., and Hewitt, C. N.: Monoterpene emissions from soil in a Sitka spruce forest, Atmos. Environ., 35, 4081-4087, 2001.

Hellén, H., Hakola, H., Pystynen, K.-H., Rinne, J., and Haapanala, S.: $\mathrm{C}_{2}-\mathrm{C}_{10}$ hydrocarbon emissions from a boreal wetland and forest floor, Biogeosciences, 3, 167-174, doi:10.5194/bg-3-1672006, 2006 .
Helmig, D., Revermann, T., Pollmann, J., Kaltschmidt, O., Hernández, A. J., Bocquet, F., and David, D.: Calibration system and analytical considerations for quantitative sesquiterpene measurements in air, J. Chromatogr. A, 1002, 193-211, 2003.

Helmig, D., Apel, E., Blake, D., Ganzeveld, L., Lefer, B. L., Meinardi, S., and Swanson, A. L.: Release and uptake of volatile inorganic and organic gases through the snowpack at Niwot Ridge, Colorado, Biogeochemistry, 95, 167-183, 2009a.

Helmig, D., Seok, B., Williams, M. W., Hueber, J., and Sanford Jr., R.: Fluxes and chemistry of nitrogen oxides in the Niwot Ridge, Colorado, snowpack, Biogeochemistry, 95, 115-130, $2009 \mathrm{~b}$.

Högberg, P., Högberg, M. N., Göttlicher, S. G., Betson, N. R., Keel, S. G., Metcalfe, D. B., Campbell, C., Schindlbacher, A., Hurry, V., Lundmark, T., Linder, S., and Näsholm, T.: High temporal resolution tracing of photosynthate carbon from the tree canopy to forest soil microorganisms, New Phytol., 177, 220-228, 2008.

Holzinger, R., Lee, A., Paw, K. T., and Goldstein, U. A. H.: Observations of oxidation products above a forest imply biogenic emissions of very reactive compounds, Atmos. Chem. Phys., 5, 67-75, doi:10.5194/acp-5-67-2005, 2005.

Ilvesniemi, H., Levula, J., Ojansuu, R., Kolari, P., Kulmala, L., Pumpanen, J., Launiainen, S., Vesala, T., and Nikinmaa, E.: Long-term measurements of the carbon balance of a boreal Scots pine dominated forest ecosystem, Boreal Environ. Res., 14, 731753, 2009.

Janson, R.: Monoterpene emissions from Scots Pine and Norwegian Spruce, J. Geophys. Res., 98, 2839-2850, 1993.

Kähkönen, M. A., Wittmann, C., Kurola, J., Ilvesniemi, H., and Salkinoja-Salonen, M. S.: Microbial activity of boreal forest soil in a cold climate, Boreal Environ. Res., 6, 19-28, 2001.

Kos, G. and Ariya, P. A.: Volatile organic compounds in snow in the Quebec-Windsor Corridor, J. Geophys. Res., 115, D01302, doi:10.1029/2009JD012391, 2010.

Kulmala, M., Hameri, K., Mäkelä, J. M., Aalto, P. P., Pirjola, L., Väkevä, M., Nilsson, E. D., Koponen, I. K., Buzorius, G., Keronen, P., Rannik, Ü., Laakso, L., Vesala, T., Bigg, K., Seidl, W., Forkel, R., Hoffmann, T., Spanke, J., Janson, R., Shimmo, M., Hansson, H.-C., O’Dowd, C., Becker, E., Paatero, J., Teinilä, K., Hillamo, R., Viisanen, Y., Laaksonen, A., Swietlicki, E., Salm, J., Hari, P., Altimir, N., and Weber, R.: Biogenic aerosol formation in the boreal forest, Boreal Environ. Res., 5, 281-297, 2000.

Lappalainen, H. K., Sevanto, S., Bäck, J., Ruuskanen, T. M., Kolari, P., Taipale, R., Rinne, J., Kulmala, M., and Hari, P.: Daytime concentrations of biogenic volatile organic compounds in a boreal forest canopy and their relation to environmental and biological factors, Atmos. Chem. Phys., 9, 5447-5459, doi:10.5194/acp-9-5447-2009, 2009.

Leff, J. W. and Fierer, N.: Volatile organic compound (VOC) emissions from soil and litter samples, Soil Biol. Biochem., 40, 16291636, 2008.

Lehning, M., Bartelt, P., Brown, B., Russi, T., Stöckli, U., and Zimmerli, M.: SNOWPACK moldel calculations for avalanche warning based upon a network of weather and snow stations, Cold Reg. Sci. Technol., 30, 145-157, 1998.

Lehning, M., Bartelt, P., Brown, B., and Fierz, C.: A physical SNOWPACK model for the Swiss avalanche warning service. Part III. Meteorological forcing, thin layer formation and evaluation, Cold Reg. Sci. Technol., 35, 169-184, 2002a. 
Lehning, M., Bartelt, P., Brown, B., Fierz, C., and Satyawali. P.: A physical SNOWPACK model for the Swiss avalanche warning. Part II. Snow microstructure, Cold Reg. Sci. Technol., 35, 147167, 2002b.

Lundy, C., Brown, R. L., Adams, E. E., Birkeland, K. W., and Lehning, M.: A statistical validation of the SNOWPACK model in a Montana climate, Cold Reg. Sci. Technol., 33, 237-246, 2001.

Poling, B. E., Prausnitz, J. M., and O'connell, J. P.: The Properties of Gases and Liquids, 5th ed. McGraw-Hill, New York, USA, 2000.

Pumpanen, J., Ilvesniemi, H., Kulmala, L., Siivola, E., Laakso, H., Kolari, P., Helenelund, C., Laakso, M., Uusimaa, M., and Hari, P.: Respiration in boreal forest soil as determined from carbon dioxide concentration profile, Soil Sci. Soc. Am. J., 72, 11871196, 2008.

Pumpanen, J., Longdoz, B., and Kutsch, W. L.: Field measurements of soil respiration: principles and constraints, potentials and limitations of different methods, in: Soil Carbon Dynamics; An Integrated Methodology, edited by: Kutsch, W. L., Bahn, M., and Heinemeyer, A., Cambridge University Press, Cambridge, UK, 27-44, 2009.

Rasmus, S., Grönholm, T., Lehning, M., Rasmus, K., and Kulmala, M.: Validation of the SNOWPACK-model in five different snow zones in Finland, Boreal Environ. Res., 12, 467-488, 2007.

Ruuskanen, T. M., Kolari, P., Bäck, J., Kulmala, M., Rinne, J., Hakola, H., Taipale, R., Raivonen, M., Altimir, N., and Hari, P.: On-line field measurements of monoterpene emissions from Scots pine by proton-transfer-reaction mass spectrometry, Boreal Environ. Res., 10, 553-567, 2005.

Schindlbacher, A., Zechmeister-Boltenstern, S., Kitzler, B., and Jandl, R.: Experimental forest soil warming: response of autotrophic and heterotrophic soil respiration to a short-term $10^{\circ} \mathrm{C}$ temperature rise, Plant Soil, 303, 323-330, 2008.
Seok, B., Helmig, D., Williams, M. W., Liptzin, D., Chowanski, K., and Hueber, J.: An automated system for continuous measurements of trace gas fluxes through snow: an evaluation of the gas diffusion method at a subalpine forest site, Niwot Ridge, Colorado, Biogeochemistry, 95, 95-113, 2009.

Staudt, M., Bertin, N., Hansen, U., Seufert, G., Ciccioli, P., Foster, P., Frenzelg, B., and Fugit, J.-L.: Seasonal and diurnal patterns of monoterpene emissions from Pinus pinea (L.) under field conditions, Atmos. Environ., 31, 145-156, 1997.

Tarvainen, V., Hakola, H., Hellén, H., Bäck, J., Hari, P., and Kulmala, M.: Temperature and light dependence of the VOC emissions of Scots pine, Atmos. Chem. Phys., 5, 989-998, doi:10.5194/acp-5-989-2005, 2005.

van Roon, A., Parsons, J. R., te Kloeze, A.-M., and Govers, H. A. J.: Fate and transport of monoterpenes through soils. Part I. Prediction of temperature dependent soil fate model input-parameters, Chemosphere, 61, 599-609, 2005.

Vesala, T., Launiainen, S., Kolari, P., Pumpanen, J., Sevanto, S., Hari, P., Nikinmaa, E., Kaski, P., Mannila, H., Ukkonen, E., Piao, S. L., and Ciais, P.: Autumn temperature and carbon balance of a boreal Scots pine forest in Southern Finland, Biogeosciences, 7, 163-176, doi:10.5194/bg-7-163-2010, 2010.

Zeller, K. and Hehn, T.: Ozone deposition in a snow-covered subalpine spruce-fir forest environment, in: Biogeochemistry of Seasonally Snow-Covered Catchments, edited by: Tonnessen, K. A., Williams, M. W., and Tranter, M., IAHS Press, Wallingford, UK, 17-22, 1995. 